\title{
Las políticas de la amistad en La Celestina: el caso de Pármeno
}

\author{
Vicente Bernaschina Schürmann \\ Universität Potsdam
}

De los distintos vuelcos de la Fortuna que se producen en el desarrollo de La Celestina, es posible decir que el más sarcástico de todos es la muerte de la alcahueta en manos de sus "confederados» Sempronio y Pármeno; y es sarcástico no por la abyecta y sangrienta traición que implica el asesinato, sino por la injerencia directa que tienen las acciones de Celestina en construir tal «confederación». Fue ella misma la que, en su afán de limpiar el camino de cualquier obstáculo que pudiera entorpecer su negocio con Calisto, se esforzó, primero, por romper la lealtad de Pármeno hacia su amo y, segundo, por pretender tornar tal fidelidad en su provecho, conminando la amistad del joven con Sempronio.

Celestina, absolutamente confiada de sus habilidades retóricas, no duda en que sus secuaces sacarán provechos propios del idiotizado Calisto y que, en consecuencia y a pesar de haber concitado lo contrario, no tendrá que repartir sus ganancias monetarias con ellos. Como se aprecia en su desenlace, estos dos excesos que la afectan - la soberbia y la avaricia-, son los que precisamente la hacen incapaz de prever la persistente reticencia de Pármeno hacia ella y cómo lentamente ésta genera también una resistencia en Sempronio. Dado el recelo y el resentimiento provocado en los sirvientes por las continuas evasivas de Celestina en relación con la repartición de las ganancias, estos terminan por asesinarla y mueren absurdamente tratando de huir de la justicia.

Considerando este complejo encadenamiento de sucesos que se desenvuelve entre los actos I y XII, y en el que se contraponen ideas, puntos de vista, deseos y sospechas de cada uno de los personajes involucrados, y partiendo de la idea sostenida por Louise Fothergill-Payne en Seneca and Celestina sobre que uno de los aspectos más originales de la obra se debe principalmente a la efectiva ficcionalización de la sentenciosa moralidad 
de su época, ${ }^{1}$ pienso imprescindible notar al menos dos cosas fundamentales: primero, la centralidad que ocupa el tema de la amistad en cuanto medio y fin para romper relaciones sociales de subordinación, tanto como para intentar rehacerlas; y segundo, la inseparabilidad del periplo presentado por Pármeno en la obra, para dilucidar los alcances y consecuencias de lo que se presenta como una crisis de las relaciones sociales y políticas tematizadas por la idea de la amistad. En palabras más generales, me parece que la amistad dentro de La Celestina se tematiza ficci nalmente como una institución ético-política en disputa y de cuya dilucidación racional y juiciosa depende el orden y el destino de la sociedad.

En este sentido, llama significativamente la atención, tal como lo indica Juan P. Gil-Oslé, la falta de comentarios directos hacia este tema en los estudios sobre La Celestina. ${ }^{2}$ Parece extraño que habiendo tantos textos que discuten su relación paródica con la ficción sentimental, el amor cortés y discursos afines, no exista otra extendida tradición que ya haya indagado este otro tipo de relación amorosa; sobre todo, considerando la importancia que tuvo el tema en los tratados políticos de la época y en los siglos inmediatamente posteriores. ${ }^{3}$

Estando esta tradición sin desarrollo, el artículo de Gil-Oslé se presenta uno de los primeros que considera a la amistad como un problema central para la comprensión de La Celestina, ya que, como bien lo destaca, se encuentra presente en toda la obra: desde los consejos de "el autor a un su amigo", pasando por la funesta confederación ya mencionada, hasta las relaciones finales entre Elicia y Areúsa. Ahora bien, para él, la presencia de este tema resulta sólo nominal. Su argumento sostiene que, si bien en La Celestina se debate y discute largamente sobre la amistad a partir de las ideas de Aristóteles y Cicerón establecidas en la época, estas no aparecen encarnadas en la obra. Por lo tanto, Gil-Oslé interpreta que las relaciones degradadas de Pármeno, Sempronio y Celestina no son sólo una parodia de las ideas filosófica señaladas, sino también la revelación de «la false-

1.- Louise Fothergill-Payne, Seneca and Celestina, Cambridge, Cambridge UP, 1988, p. 44.

2.- Juan P. Gil-Oslé, "La Amistad, el remedio de la Fortuna en La Celestina», Celestinesca, 29 (2005), pp. 171

3.- Sobre los aspectos paródicos de la ficción sentimental en La Celestina se pueden consultar los textos de Dorothy Sherman Severin, "La parodia del amor cortés en La Celestina», Edad de Oro, 3 (1984), pp. 275-279 y de María Eugenia Lacarra, «La parodia de la ficción sentimental en La Celestina» Celestinesca, 13.1 (1989), pp. 11-30. Respecto de la evolución del problema ético-político de la amistad en el pensamiento medieval recomiendo el artículo de John von Heyking, "The Luminous Path of Friendship: Augustine's Account of Friendship and Political Order", en Friendship \& Politics: Essays in Political Thought, ed. John von Heyking and Richard Avramenko, Notre Dame, U of Notre Dame P, 2008, pp. 115-38. Para observar la evolución de estas ideas a partir del siglo Xvi en Europa es significativo el caso de los ensayos de Montaigne "De la amistad» y "De la tiranía» y el texto sobre la Servidumbre Voluntaria de su amigo La Boétie, escritos alrededor de 1570, sobre todo en relación a la idea de que la amistad está incluso por encima del respeto irrestricto a la ciudadanía. Véase David Lewis Schaefer (ed.), Freedom over Servitude: Montaigne, La Boétie, and On voluntary servitude, Westport, Greenwood Press, 1998. 
dad de ciertos sistemas de pensamiento filosófic sobre la amistad que en realidad no tenían otro objetivo que la defensa de los intereses políticos y económicos de un determinado grupo social». ${ }^{4}$ De tal modo que, según su opinión, "las palabras amigo y amistad no sirven más que para tratar de intrigas, de sexo, y para esconder los intereses, la desconfianza y la cobardía de los confederados» (186).

Dado este problema y citando ejemplos de Petrarca, Boccaccio y Fregoso, Gil-Oslé indica cómo para la época «la amistad se presenta como un factor de cohesión social que ayuda al individuo a sobrellevar los efectos de los cambios de la fortuna» (192). Como en el funesto desenlace de La Celestina no hay, según él, mucha cabida para la risa o el optimismo, es necesario recurrir al marco general de la obra para encontrar algún sentido al llanto de Pleberio. Así, tomando en cuenta el prólogo de "El autor a un su amigo", Gil-Oslé arguye la manera en la que "el autor se erige en el mejor ejemplo de amicita vera al amonestar, aconsejar y castigar, a la manera petrarquista» a su amigo (real o imaginario), a través del carácter anti-ejemplar enfatizado a lo largo de la Tragicomedia» (193).

En un sentido general, sus conclusiones me parecen importantes, pues logran hacer énfasis en la amistad en la obra, exponiendo los contactos y deudas de las sentencias morales de La Celestina con ideas manejadas por obras que se han demostrado sus fuentes directas. No obstante, pensando un poco más en el sutil desarrollo de la acción y en los modos en cómo se construye el mundo social en la obra, me parece que su interpretación no sale de la comprensión moral del mundo celestinesco como un mundo al revés o un anti-ejemplo, y no alcanza a precisar ciertos detalles que corresponden a los aspectos, a mi entender, más atractivos de la obra: a saber, las disputas sobre la idea de amistad de Pármeno y Celestina, su confrontación con las relaciones sociales desplegadas en la obra y el grado de agencia que tienen éstas en la muerte de ambos y en la de Sempronio.

En mi opinión, la vida y muerte de Pármeno, sus propias preocupaciones y puntos de vista sobre el tema, la seducción realizada por Celestina y su persistente resistencia a ella, son elementos imprescindibles para comprender el momento crítico que vivía el pensamiento ético y político de la época frente a las transformaciones de la sociedad, provocadas por el debilitamiento del sistema feudal tradicional y la emergencia de un sistema comercial monetario.

Haciendo un breve recorrido por la crítica celestinesca es fácil notar que Pármeno resulta un personaje más que atractivo. Sin contar el protagonismo de la alcahueta y su incomparable discurso, se puede decir que, junto con Melibea, es uno de los personajes más móviles y dinámicos. Por supuesto, eso no es todo; como lo señala Joseph T. Snow en "¿Cómo pagaré esto?': The Life and Death of Pármeno», la particularidad del caso 
de Pármeno no se sustenta únicamente en las transformaciones radicales que experimenta, sino también en la posibilidad que tiene él mismo y el lector-receptor a lo largo de la acción de contemplar y hacerse consciente paso a paso de aquella transformación. ${ }^{5} Y$ si eso no es suficiente, hay que indicar que este periplo ha sido interpretado por gran parte de la crítica como una prolongada batalla en la que se observa una mezcla particular entre determinación personal (libertad) y destino (fatum), que culmina en la perversidad y la muerte. ${ }^{6}$

En relación con esta batalla y la final caída de Pármeno, me parece interesante que para la mayoría de estos críticos el carácter de ésta dice relación con una naturaleza perversa que determina al personaje desde su origen y que es provocada por la seducción celestinesca a la que es sometido en la escena décima del acto primero. La bruja, sirviéndose de una triple tentación basada en premisas escolásticas —la lujuria/carne (Concupiscentia carnis), la avaricia/mundo (Concupiscentia occulorum) y la presunción/Demonio (Superbia vitae)—, logra desviar a Pármeno en sus vanos esfuerzos por afincarse en el bien (la armónica relación entre sirviente y amo en términos cristianos) para llevarlo a gozar de las alegrías o placeres de la amistad en un mundo engañoso, perverso y demoniaco.? Así, por ejemplo, para Truesdell, Pármeno pasa de la correcta Imitatio Christi a una viciada Imitatio Adamis, ${ }^{8}$ mientras que para Heusch, el mozo encarna un proceso de satanización, que se corresponde con un imaginario angélico de la caída. ${ }^{9}$

Tales argumentos me interesan, porque, según se desenvuelven, parecen sostener, primero, que la batalla de Pármeno entre determinación y destino sólo puede suceder entre dos polos: el bien, caracterizado por la aceptación de las jerarquías ético-políticas del mundo, el servicio al amo/ Dios de la sociedad cortesana-feudal tradicional, o el mal, dispuesto por el desorden egoísta, lujurioso y soberbio de la nueva sociedad que emerge de los ricos ennoblecidos y la permisividad de su ocio y derroche. Y segundo, que a través de la inevitabilidad de su muerte se tiende a acep-

5.- Joseph T. Snow, “¿Con qué pagaré esto?': The Life and Death of Pármeno», en The Age of the Catholic Monarchs, 1474 - 1516: Literary Studies in Memory of Keith Whinnom, ed. Alan Deyermond and Ian Macpherson, Liverpool, Liverpool UP, 1989, p. 185.

6.- Ibidem, 191. Véanse también los artículos de Carlos Heusch, «Las desviaciones de Pármeno o la caída de un ángel», Celestinesca, 26 (2000), p. 42; de Emilio Barón Palma, «Pármeno: La liberación del ser auténtico, el antihéroe», Cuadernos Hispanoamericanos, 317 (1976), p. 400; y de William D. Treusdell, «Pármeno's Triple Temptation: Celestina, Act I», Hispania, 58.2 (1975), p. 274.

7.- Al respecto puede verse también el análisis análogo que hace, para el caso de Melibea, Reinaldo Ayerbe-Chaux, "La triple tentación de Melibea», Celestinesca, 2.2 (1978), pp. 3-12.

8.- William D. Treusdell, Op. cit., 275.

9.- Carlos Heusch, Loc. cit. 
tar sin cuestionamientos la naturaleza perversa de Pármeno debido a su linaje como un tema que caracteriza al mundo de La Celestina en general.

De ser cierta esta última premisa, me parece absurdo el contrapunto incorporado por las palabras de Areúsa sobre la independencia y la libertad en el banquete celebrado en casa de Celestina; sobre todo considerando el deseo que empuja a Pármeno hacia ella, la relación de amistad que demuestra con Elicia después de la muerte de los confederados y el hecho de que ninguna de las dos sea parte de los fúnebres desenlaces a pesar de su participación e ideas.

Momentos antes de que aparezca Lucrecia en casa de la alcahueta para notificar que Melibea muere de amor por Calisto, Areúsa, discutiendo este tipo de argumentos naturalizadores del linaje en la sociedad, declara que «las obras hacen linaje; que, al fin, todos somos hijos de Adán y Eva. Procure de ser cada uno bueno por sí y no vaya a buscar en la nobleza de sus pasados la virtud» (IX, 2, 423). ${ }^{10}$ Luego, una vez llega Lucrecia, Areúsa confirma sus ideas con orgullo al enfatizar que «estas que sirven a señoras ni gozan deleyte ni conocen los dulces premios del amor» (IX, 3, 428), que «jamás me precié de llamarme de otrie sino mía» (Ix, 3, 429) y que, "por eso, madre, he quesido más vivir en mi pequeña casa, esenta y señora, que no en sus ricos palacios, sojuzgada y cativa» (Ix, 3, 430-31). Potentes declaraciones que tienen que ser confrontadas con las ideas de Pármeno sobre la virtud honesta que él, siguiendo a Séneca, entiende como "pobreza alegre» $(\mathrm{I}, 10,275)$ y con los ofrecimientos que le hace Celestina a él en su segunda confrontación, justo antes de subyugarlo mediante la misma Areúsa: «¿A qué llamas [vivir] reposado, tía?» pregunta Pármeno. «Hijo, a vivir por ti,» responde Celestina, «a no andar por casas agenas, lo qual no andarás mientra no te supieres aprovechar de tu servicio» (vI, 1, 375).

Como se observa, el problema de la sujeción, el determinismo y las diversas opciones de vida que se presentan en las palabras de los personajes hacen al mundo celestinesco mucho más complejo que una simple inversión del universo en el que, como se queja Pármeno al inicio, «a los traydores los llaman discretos, a los fieles, nescios» (III, 4, 293). No resulta gratuito, entonces, que en el origen de las transformaciones de Pármeno y de todo este embrollo se hallen las reflexiones sobre la amistad. Estas no deben considerarse sólo como un argumento más de Celestina para seducir a Pármeno, sino como una idea política y secular de vital consideración a la hora de pensar en la sociedad y su crisis. Como veremos, las reflexiones de Pármeno y de Celestina sobre ésta, si bien entrelazan tradiciones comunes, proceden de distintos enfoques y tienen distintas

10.- Todas las referencias a La Celestina corresponden a la edición de Peter E. Russell, publicada en Clásicos Castalia y citada en la bibliografía. De aquí en adelante, para facilitar la referencia, la citaré señalando el acto, la escena y luego el número de página. De tal forma, (IX, 2,423 ) equivale al acto noveno, escena segunda, página cuatrocientos veintitrés de la edición ya señalada. 
funciones. Pármeno acepta los argumentos de Celestina como válidos, pero se resiste a creer en el modo en cómo la vieja los pone en acción. Gracias a ella adquiere un saber revelador con el que es capaz de ver que la amistad virtuosa que pretende con Calisto es imposible, en vistas a que la mentalidad de su amo no comparte aquellos ideales; pero también ese saber revelador, sumado a su propio discernimiento, le permite ver que tampoco Celestina ni Sempronio podrían satisfacer tales ideales.

Snow lo argumenta de manera similar en su artículo sobre Claudina: Celestina es la que hace a Pármeno encarar la naturaleza de sus acciones e ideas y con ello corta cualquier esperanza sobre las compensaciones que la lealtad puede traerle en este mundo. ${ }^{11}$ Sin embargo, para Snow, la naturaleza de Pármeno es perversa y violenta, y por lo tanto sus acciones quedan justificadas de antemano en esa mezcla entre origen (Claudina) y destino (la confederación). Personalmente, me interesa suspender el juicio sobre la naturaleza de Pármeno y su final, para volcarme a pensar, más bien, las posibles diferencias que pueden haber entre las ideas de este personaje sobre la virtud y la amistad y las presentadas por Celestina, ya que, justamente es este debate desatado por la alcahueta el que nos deja ante un personaje cuya característica principal es la de transitar por el resto de la obra sin una afiliación político-moral clara, imposibilitado de reconocerse en ninguno de los órdenes de mundo ofrecidos a él: ni el de Calisto, ni el de Celestina, ni el de Sempronio.

Desde el acto I, Pármeno se muestra como un sujeto con ideas propias. A pesar de ser el criado de Calisto, no tiene problemas en disentir con él y aconsejarlo sobre la llegada de Sempronio y Celestina (I, 7, 255-56). Por supuesto, tales ideas y su actitud hacia Calisto van de la mano con su propio concepto de virtud, afincado en las esperanzas que tiene en su amistad con él. Por lo mismo, cuando se arriesga al consejo y a revelar también sus orígenes -el servicio que prestó por un mes en casa de la vieja-, sufre una primera desilusión al recibir como respuesta una reconvención por parte del amo, acusándolo de envidioso por las mercedes ofrecidas a Sempronio en el negocio con la alcahueta $(\mathrm{I}, 7,264) .{ }^{12}$

Celestina, percibiendo precisamente esta situación, alude al tema apenas puede quedarse a solas con Pármeno: "porque virtud nos amonesta sufrir las tentaciones y no dar mal por mal y especial quando somos tentados por moços, no bien instrutos en lo mundano, en que con necia lealtad pierdan a sí y a sus amos, como agora tú a Calisto» (I, 10, 268). A lo

11.- Joseph T. Snow, "Celestina's Claudina», en Hispanic Studies in Honor of Alan D. Deyermond: A North American Tribute, ed. John S. Miletich, Madison, The Hispanic Society of Medieval Studies, 1986, p. 270.

12.- Snow, en su artículo “¿Cómo pagaré esto?”», Op. cit., p. 187, interpreta en estas oraciones cierta agudeza de Calisto, quien descubre a Pármeno envidiando a Sempronio. Sea como sea, a mí me interesa más el hecho de que tales palabras provocan en Pármeno una conciencia sobre las diferencias entre lo que él cree sobre Calisto y lo que efectivamente es Calisto. 
que Pármeno responde del siguiente modo: «Calla, madre, no me culpes ni me tengas, aunque moço, por insipiente. Amo a Calisto porque le devo fidelidad, por criança, por beneficios, por ser dél honrrado y bientratado, que es la mayor cadena que el amor del servidor al servicio del señor prende, quanto lo contrario aparta» (I, 10, 269-70). ${ }^{13}$

Dado el orden de los elementos señalados por Pármeno en los que se sustenta la deuda que origina la fidelidad que siente hacia su amo y su claro asentamiento en un orden social tradicional, Celestina busca destruirlos argumentalmente uno por uno. Sin embargo, no es algo que sucedería sin que Pármeno cometiera antes un error en la disputa. Por un arranque de soberbia, Pármeno revela el secreto que le permite desconfiar absolutamente de las palabras de Celestina y con ello, sin saberlo, comienza a perder su libertad. Al revelarle a Celestina que es hijo de su compadre Alberto y que sirvió en su casa cuando niño, le entrega a Celestina todas las armas para que esta destruya uno a uno los fundamentos de su fidelidad con Calisto.

Enterada de los orígenes de Pármeno, Celestina desbarata primero la fidelidad por crianza. Aprovechando la débil memoria que debe existir de su madre, Celestina no sólo la presenta como su igual, sino que le enrostra que, finalmente, no fue ni ella ni Calisto quienes lo criaron, sino ella en su casa y con sus medios (I, 10, 271). Segundo, con respecto a los beneficios, Celestina, sin pensar mucho en las ideas del joven sobre la honestidad y la pobreza, se inventa una historia sobre la herencia dejada a Pármeno por su padre y "que basta más que la renta de tu amo Calisto» (I, 10, 272). Luego, acaso porque nota que su historia no logra dar en el blanco, Celestina toma un giro en relación con los beneficios y apunta al aislamiento y soledad en la que debe encontrarse, dado sus años de peregrinaje de servicio en servicio. Posiblemente recordando lo que Pármeno ha dicho al inicio de su confrontación sobre su amor a Calisto y el dolor que le provoca verlo sin juicio debido al amor, y sobre la mala opinión que tiene de Sempronio, quien da necios consejos a su amo y "piensa sacar aradores a pala y açadón» (I, 10, 270), Celestina pone el dedo en la llaga. Pármeno sufre porque intenta ser sabio siendo joven y feliz en la pobreza y evidentemente, mirando a quienes lo rodean, no tiene a nadie con quien compartir sus deseos e ilusiones. Por lo tanto, Celestina, haciéndose portadora de una sabiduría afincada en la experiencia, le dice: «dexa los vanos prometimientos de los señores, los quales desechan la substancia de sus sirvientes con huecos y vanos prometimientos. Como la sangui-

13.- Es curioso que habiendo Alan Deyermond notado las transacciones amorosas y mágicas entre Calisto, Celestina y Melibea con la magia a través de la transformación de un símbolo en los objetos: hilado, cordón y cadena, no haya nadie que haya percibido la presencia del motivo en el primer acto en relación con la fidelidad de Pármeno y sus ideas sobre el amor entre amo y sirviente. Véase Alan Deyermond, «Hilado-Cordón-Cadena: Symbolic Equivalence in La Celestina», Celestinesca, 1.1 (1977), pp. 6-12. 
juela saca la sangre, desagradecen, injurian, olvidan servicios, niegan galardón» (I, 10, 274). El golpe es doble y certero. Con éste demuestra que Pármeno no sólo no ha ganado beneficios con Calisto, sino que tampoco los tendrá. Calisto, como todos los señores, se ama más a sí mismo que a los suyos y, en consecuencia, no hay tampoco honra ni buenos tratos posibles. Y aquí agrega, a favor de sus intereses, que tal comportamiento no es un error, sino el único modo de vivir y medrar, para lo cual «mucho te aprovecharás siendo amigo de Sempronio» (I, 10, 275).

Justamente aquí es el momento en que Pármeno queda "perplexo", ya que las palabras de Celestina resuenan con fuerza en la experiencia vivida recientemente con Calisto, a pesar de ir en contra de lo que él estima como última virtud, si bien desea riqueza:

no querría bienes mal ganados [...] Pues yo con ellos no viviría contento, y tengo por onesta cosa la pobreza alegre. Y aun más te digo: que no los que poco tienen son pobres, mas los que mucho desean. Y por esto, aunque más digas, no te creo en esta parte. Querría pasar la vida sin embidia, los yermos y la aspereza sin temor, el sueño sin sobresalto, las injurias [sin] respuesta, las fuerzas sin denuesto, las premias con resistencia. (I, 10, 275)

Pármeno se muestra intransigente en sus ideales. Celestina busca repetir los argumentos sobre la amistad, viendo que en un principio habían tenido efecto. De modo que alude a máximas estoicas y aristotélicas a la vez para demostrar la inadecuación de sus deseos de amistad con Calisto y argumentar cómo es posible que con Sempronio logre una amistad perfecta: por bien, por provecho y por deleite. Indicando que con este último, a diferencia que con Calisto, poseen similar estado, voluntad y virtud; ambos desean riqueza y pueden asociarse para enriquecerse por la situación; y, por último, entre los dos, en cuanto jóvenes, pueden compartir «todo linaje de plazer» (I, 10, 276).

Tanto Gil-Oslé como Fothergill-Payne han demostrado los claros puntos de contacto de esta dilucidación sobre la amistad con los de la filos fía aristotélica y estoica; el primero, como ya lo mencioné más arriba, para indicar cómo desde el inicio se construye en la obra una desfiguración de la amistad, y el segundo, para señalar la manera cómo las «fontezicas de filosophía» que componen los diálogos son reutilizadas o tergiversadas para lograr ciertos efectos. Así, interpreta que Pármeno, en tanto joven inexperto, termina perdiendo ante Celestina, en la medida en que ella aprovecha de mucho mejor manera las fuentes y los temas a tratar. ${ }^{14}$

Ahora bien, me parece fundamental que, a pesar de todos los modos mediante los que Celestina busca convencer a Pármeno de que se amiste 
con Sempronio, éste persevera en la desconfianza. Si bien en la discusión se cuela la mención de Areúsa y Pármeno, ingenuamente revela el deseo que siente por ella, esto no hay que confundirlo con los argumentos sobre la amistad. A pesar de que pareciera que el tema de la amistad con Sempronio se inclina hacia una amistad por deleite e interés, dado el ofrecimiento de la vieja a Pármeno de conseguirle a Areúsa, me parece que hay que considerarlo como un tema paralelo, vinculado al contrato que funda a la confederación y que no toca el concepto de amistad. En efecto, Pármeno insiste en dejar fuera de este asunto a Sempronio, ya que «Sempronio en su exemplo no me hará mejor, ni yo a él sanaré su vicio» (I, 10, 277), además que prefiere mantener en secreto cualquier posible vencimiento por deleite que vaya en contra de la virtud (I, 10, 277). Es entonces cuando la vieja vuelve a insistir en que ambos son semejantes y que podrán gozar mucho más al conversar sobre sus deleites con las «mochachas.»

Al final, dada la testarudez de Pármeno, Celestina se harta y decide cortar toda negociación con él. Pármeno, viendo que su actitud le está restando posibilidades de acceder a Areúsa, decide finalmente enmendarse ante la alcahueta y acceder a la "paz con Sempronio", ya que "la paz no se debe negar [...] Amor no se debe rehuyr [ni] caridad a los hermanos. [...] Por eso, perdóname, háblame; que no sólo quiero oyrte y creerte, mas en singular merced rescibir tu consejo. Y no me lo agradezcas, pues el loor y las gracias de la acción más al dante que no al recibiente se deven dar» (I, 10, 280).

Considerando esta conclusión de la disputa entre Pármeno y Celestina indicando la "singular merced» que implica recibir consejos de otro - mercedes que Celestina momentos antes ya había indicado que no eran posibles de pagar (I, 10, 279)—, me parece que es el momento en que la discusión sobre la amistad y sus relaciones virtuosas y desinteresadas chocan con el problema económico que afecta a la constitución de las relaciones sociales de subordinación.

Pármeno, quien se considera fiel servidor de Calisto, parece darse cuenta de que ha cometido dos graves errores en su discusión con Celestina; al revelarle su pasado y sus deseos, percibe que ha perdido parte de la libertad relativa de la que goza. Teniendo discernimiento, Pármeno sabe que en las actuales circunstancias su amistad con Calisto es imposible, sin embargo parece conservar una pequeña esperanza de que puede reconstruir el lazo, siempre y cuando Calisto retorne a la razón (II, 3, 291). Como se aprecia, durante este acto, el sirviente busca aconsejar a su amo por última vez en relación a la embajada de Celestina, teniendo en mente lo que le acaba de suceder a él mismo. Calisto ha entregado dineros a Celestina, lo que implica el inicio de un negocio, pero no sólo eso, sino que se ha hecho su cautivo, "porque a quien dizes el secreto das tu libertad» (II, 3, 289). Viendo que sus consejos son nuevamente mal recibidos por Calisto e interpretados como "palabras vanas,» «lisonjas,» «malicias» 
y «embidias,» y notando cómo él es el único sirviente que está efectivamente trabajando en casa, Pármeno reniega de cualquier posible amistad o bienaventuranza con su amo (II, 3, 293). No obstante, como se aprecia luego en el Acto vil, esto no significa que pase de inmediato al servicio de Celestina, sino que su papel será el de desconfiar tanto de Calisto como de la vieja, intentando aprovecharse de Sempronio para desprenderse de la engañosa deuda que la alcahueta lo hace contraer en el momento en que le entrega a Areúsa (VII, 3, 292-93). Notando, entonces, la conjunción de amistad, deseos y relaciones de sujeción (sustentadas unas en promesas y otras en dinero), es donde veo que el modelo de mundo que presenta La Celestina es más complejo que una simple oposición entre amos y sirvientes, adinerados y pobres, viles y perversos.

En su ya clásico El mundo social de La Celestina, José Antonio Maravall sostiene que esta obra presenta «el drama de la crisis y la transmutación de los valores sociales y morales que se desarrolla en la fase de crecimiento de la economía, de la cultura y de la vida entera, en la sociedad del siglo XV». ${ }^{15} \mathrm{Tal}$ crisis, como se aprecia en el tema central del «Prólogo» agregado a la Tragicomedia, viene marcada justamente por la pérdida de la unidad y armonía en el orden del mundo tradicional, en la medida que éste comienza a resquebrajarse con el debilitamiento del sistema feudal y la emergencia de una economía monetaria. Tal debilitamiento promueve la sensación de variedad y contraposición que, según Maravall, fue vivida intensamente por los hombres del siglo Xv. ${ }^{16}$

Una de las causas principales de este resquebrajamiento y transformación radical en las relaciones sociales es la toma de fuerza que tuvo precisamente la economía monetaria durante el siglo XV, cuyas consecuencias fueron la conmutación de tributos en especies y de los servicios personales en pago por dinero. Esta transformación, por supuesto, presenta un lado que puede interpretarse de manera positiva y, otro de manera negativa. Por una parte, siguiendo a Alfred von Martin y su Sociología del Renacimiento, Maravall indica que en la economía natural (feudal) el individuo está directamente ligado al grupo al que pertenece $y$, a su vez, por la reciprocidad que sustenta el sistema de intercambios y servicios, con la colectividad en general. En este sentido, la aparición del dinero sirve para emancipar al individuo, siempre y cuando el trabajo tome la forma

15.- José Antonio Maravall, El mundo social de La Celestina [1964], 3ª ed. Madrid, Editorial Gredos, 1986, p. 22

16.- En el mundo de La Celestina, esta inestabilidad de la época se ve redoblada, además, por su contexto urbano: «en un período de dependencias y limitaciones, en el que la población rural vivía más sujeta al suelo y cargada de obligaciones y trabajos serviles, que la perseguían hasta la muerte, y que se transmitían de padres a hijos. La vida en la ciudad y la libertad urbana fueron asociadas a la movilidad sin barreras, la posibilidad de cambiar de oficio y de practicar actividades de comercio, sin necesidad de permisos señoriales y bajo el amparo jurisdiccional». María Asenjo González, "La historia y la sociedad urbana en la lectura de La Celestina», Celestinesca, 32 (2008), p. 13. 
de un contrato libre, dentro del cual tanto contratistas y contratados puedan buscar un máximo de ventaja dentro de lo estipulado en el contrato. Sin embargo, por la otra, este tipo de relaciones tienden a mecanizarse, y provocan un distanciamiento recíproco de los individuos. ${ }^{17}$ Este distanciamiento es el que lleva, en consecuencia a la disolución de la sensación de unidad, a la consideración del universo como multiplicidad y confli to, y en última instancia, a las posibilidades de abuso y explotación por parte de los poderosos.

Según su modelo, esta crisis se inicia en la parte alta de la estructura social y, por lo tanto, la clase dominante se revela, sin dudas, como la responsable de las desviaciones que se experimentan en la estructura y perfil de la sociedad. Por supuesto, no hay que entender esta desviación en términos simplemente morales o intelectuales, sino más bien ideológicos y materiales. La clase dominante determina a la sociedad en general porque domina los recursos que la sociedad en cuestión dispone. Así, determina el sistema de funciones, el cuadro de deberes y derechos y la figura moral de cada uno de los grupos que componen el entramado social. ${ }^{18}$

En este sentido, según Maravall, el mundo social que representa $\mathrm{La} \mathrm{Ce}$ lestina es el de los ricos ennoblecidos y no el de la nobleza tradicional, ya que en vez de mostrarse defensores de un orden tradicional en el que su figura es la productora de capital y la que da cohesión al mundo, se presentan renegando inconscientemente de ese orden y abusando de la posesión de ese capital para conseguir beneficios inmediatos. De tal forma, partiendo de la premisa de que las relaciones de subordinación son un motor engendrador de vida social, Maravall considera que el drama de La Celestina se desenvuelve verticalmente en una doble dirección - de amo a sirviente y de sirviente a amo-, aunque en un mundo que no logra sostener las jerarquías que fundan tal determinación. ${ }^{19}$

A pesar de que Maravall piensa la crisis del siglo XV desde los modos de producción materiales y desde ellos va hacia los aspectos morales e intelectuales de la época, me parece que la manera en que desarrolla su reflexión sobre La Celestina no alcanza a atisbar todas las complejas relaciones que se revelan en el mundo representado por la obra. Estoy de acuerdo en que Calisto y la familia de Melibea se corresponden con los comportamientos de una nobleza enriquecida en la que los valores del sistema feudal están en clara descomposición, sin embargo disiento en su diagnóstico tanto para el caso de Celestina, como para la condición de Pármeno, y por lo tanto, para el drama social que representa la obra en general.

\section{7.- José Antonio Maravall, Op. cit., pp. 70-71.}

18.- Ibidem, pp. 22-23.

19.- La división en dos clases — «una aristócrata y la plebe de criados y prostitutas que depende económicamente de ella» — también ha sido sostenida por Alan Deyermond en su artículo "Divisiones socio-económicas, nexos sexuales: La sociedad de La Celestina», Celestinesca, 8.2 (1984), p. 4. 
Mary Malcolm Gaylord, conjuntando perspicazmente algunas ideas de Peter Dunn y de Inés Azar, establece en su artículo «Fair of the World, Fair of the Word» la centralidad que tiene el comercio en La Celestina; no sólo en el léxico escogido o las relaciones económicas que se entablan, sino también en un nivel tan profundo que permea todos los niveles de significación. En la medida en que toda la obra está construida a través de actos de habla performativos aunque ficcionales, Gaylord establece que el mismo lenguaje adquiere el estatuto y reglas que rigen la economía monetaria: no sólo es el medio para conseguir cosas, sino que es en sí mismo un bien y objeto de deseo. ${ }^{20}$ En este sentido, el personaje de Celestina introduce junto con su modo de usar las palabras una nueva visión de mundo a la obra: "para Celestina, el lenguaje es tanto medio para conseguir estos fines [conocimiento, autoridad, poder, mantención física y placer] como un placer para disfrutar en sí mismo» (9). Sus manejos de lenguaje se revelan entonces un servicio que escapa en su descripción a las actividades laborales simples del sistema feudal e incluso a las de una economía monetaria en la que se intercambian riquezas por bienes concretos. El servicio ofrecido por Celestina no se acaba en la provisión de placer a cambio de un sueldo - concretar las relaciones sexuales entre Calisto y Melibea por las cien monedas de oro y la cadena-, sino en el ofrecimiento de experiencias placenteras que no pueden ser vividas fuera de ese espacio imaginario configurado por su lenguaje. En este sentido, Celestina encarna el surgimiento de una actividad económica basada en servicios cuyo capital es eminentemente simbólico.

Pármeno, quien recuerda su crianza en casa de la vieja, sabe el trasfondo de este rol e incluso pretende cumplirlo él mismo en casa de su amo, dándole consejos y señalándole qué sería más virtuoso hacer en la búsqueda de su amor con Melibea (II, 3, 289). Por supuesto, Pármeno no concuerda con el modo de operar de Celestina, no porque piense que medrar sea vicioso en sí mismo, sino porque la considera poco honesta. Cuando Pármeno expone a Calisto el oficio de la buhonera con lujo de detalle, el criado concluye rápidamente indicando que "todo era burla y mentira» (I, 6, 263). La nota al pie de Russell indica que ha habido discrepancias críticas por la manera de interpretar este juicio de Pármeno sobre las cualidades hechiceras de Celestina, ya que pone en duda que la magia que se despliega en la obra sea efectiva y eso presenta problemas que requieren de un análisis mucho más fino. Personalmente, me parece que esta declaración tiene que interpretarse en relación con el mundo ideal que se puede inferir de los consejos, argumentos y dudas que da Pármeno a Calisto y luego a Celestina.

20.- Mary Malcolm Gaylord, «Fair of the World, Fair of the Word: The Commerce of Language in La Celestina», Revista de Estudios Hipánicos, 25.1 (1991), pp. 5-6. 
Volviendo a la manera en que termina la primera discusión que tiene el sirviente con la alcahueta, es significativo que cuando acepta el trato que le ofrece con Areúsa, a pesar de reconocer que existe una tentación por lujuria, éste se las arregle para perseverar en su estoicismo: «no hay mal en reconocerse vencido por deleite contra la virtud, sino en atreverse a la honestidad no siéndolo» (I, 10, 277).

Fothergill-Payne indica que para la filosofía clásica la amistad era el lazo más importante entre los seres humanos, más que el amor o las relaciones familiares. El problema es que los filósofos no acordaban siempre en el propósito que subyacía y que animaba a la amistad. Mientras Aristóteles admitía cierta utilidad y Epicuro apuntaba solo al placer de la relación, los estoicos pregonaban un completo desinterés en la búsqueda $y$ en el mantenimiento de la amistad. En cuanto que para ellos la virtud era la condición sine qua non de todas las acciones y relaciones de los seres humanos, ellos subordinaban el placer y la ganancia al principio de la naturaleza y la razón, ya que ambas constituían tal virtud. En este sentido y a diferencia de Aristóteles, para Séneca la diferencia de estado o clase tal como la que separaba a amos y sirvientes no era obstáculo para una real amistad. Claro que la ausencia de interés demandaba una abnegación de sí al punto del sacrificio ${ }^{21}$

Justamente la seducción de Celestina lo que hace, en este sentido, es buscar confundir el estoicismo de Pármeno con aristotelismo, pasando del desinterés, en la medida en que se comparte cierto concepto de virtud sustentado en la razón, a la utilidad y el placer basados en la semejanza. Sin embargo, como se aprecia en la segunda confrontación que tienen los dos en el acto VII, Pármeno no acepta la posibilidad de amistad con Sempronio: «Con Sempronio me parece es imposible sostenerse mi amistad. El es desvariado, yo mal sofrido: conciértame esos amigos» (VII, 1, 374). Lo que dice relación con el modo en cómo él comprende las diferentes naturalezas que animan sus deseos y sus problemas con la sociedad. Entendiendo esta diferencia, Celestina le responde: «Pues no era essa tu condición». Frase que busca recuperar la consideración de la naturaleza de Pármeno en términos genealógicos y de crianza y no en términos de razón y virtud. O sea, Celestina pretende enfatizar que Pármeno es lo que es porque es hijo de Claudina y porque fue criado por ella, y que lo que experimenta ahora no es una mejora o asención social, sino una desviación de su naturaleza. Sin embargo, Pármeno presenta una idea diferente, al responderle: "A la mi fe, mientra más fui creciendo, más la primera paciencia me olvidava. No soy el que solía y así mismo Sempronio no [ha] ni tiene en que me aproveche» (VII, 1, 374). Es decir, que Pármeno defie de la posibilidad de no ser aquel que se designa mediante linaje, mientras las relaciones con otros se hagan en miras al provecho intelectual-moral, 
fundado en la persecución de un bien mayor en pos de la comunidad y no en función de un bien utilitario o beneficio común ${ }^{22}$

Como es de esperar, porque es su argumento más fuerte en contra de las ideas de Pármeno, Celestina vuelve a la interpretación aristotélica de las glosas de los traductores de Séneca. ${ }^{23}$ Así, la vieja insiste en la semejanza entre ambos y en los fines de una amistad así: ayudarse, protegerse y, por supuesto, deleitarse en la compañía de y hablando sobre mujeres. $\mathrm{Y}$ es aquí donde se recupera el tema que ya había surgido en el primer acto en relación con Areúsa y que es el que deriva la discusión sobre la amistad al espacio de las relaciones sociales y la subordinación por contratos y negocios. En efecto, Pármeno, quien demuestra su juventud y sus ansiedades masculinas, insiste en conseguir a la muchacha en este trato específico, pero no a cambio de su amistad con Sempronio. ${ }^{24}$ En la discusión que sostiene con Celestina, éste la pasa a aceptar como mujer sabia - alagándola quizás-y reconoce que ella tenía razón respecto de Calisto y sus intereses. Por supuesto, Pármeno tampoco carece de intereses y, por lo tanto, busca establecer un pacto con la alcahueta, en el que dice que la dejará hacer de las suyas y que callará, puesto que no piensa aconsejar más a Calisto porque él lo acoge mal (vII, 1, 377). Dado este primer paso, lo que sigue entonces es recordarle sobre su negocio con Areúsa. Pármeno, encara directamente a Celestina y le requiere la promesa hecha en el primer acto. La vieja, obligada de cierta manera, acepta llevarlo directamente donde la muchacha, ya que ésta le presenta la oportunidad de cerrar definitivamente la amistad del joven con Sempronio.

Areúsa, cuya relación con Celestina es demasiado compleja como para abordarla aquí, se muestra reticente ante el panorama de tener relaciones sexuales con Pármeno. La alcahueta, recordándole consejos y negocios pasados - «el amor no se paga sino con puro amor y las obras con obras», le dice (VII, 2, 388)- debe recurrir a grandes esfuerzos, retóricos y físicos, para convencerla. Estando Pármeno presente en la parte final de esta discusión, éste ve a Areúsa desnuda, lo que aumenta su deseo, a la vez que contempla cómo ésta parece negarse a que todo termine como él desea. Así, comete un tercer error en sus debates con Celestina. Arrastrado por

22.- Respecto de la idea de linaje, contrastada con las ideas de Areúsa que ya mencioné al inicio, resulta interesante pensar la presencia de una mentalidad genealógica en la época, que surge precisamente de los conflictos religiosos y raciales entre cristianos, musulmanes, judíos y conversos en la península. Véase David Nirenberg, "Mass Convertion and Genealogical Mentalities: Jews and Christians in Fifteenth-Century Spain,» Past and Present, 174 (2002), pp. 3-41. Respecto de las divisiones escolásticas entre bien común y beneficio común y sus relaciones con la amistad, es posible consultar el libro de M. S. Kempshall, The Common Good in Late Medieval Political Thought, Oxford, Oxford UP, 2000.

23.- Louise Fothergill-Payne, Op. cit., p. 64.

24.- Respecto del personaje de Pármeno y la masculinidad ansiosa que lo marca, véase el artículo de Amanda Tozer, «La identidad masculina en Celestina: la emasculación de Pármeno», Celestinesca, 27 (2003), pp. 149-46. 
su deseo, Pármeno le dice a Celestina que le dará todo cuánto tiene para que «no salga yo de aquí sin buen concierto» (vII, 3, 392). Lo que el joven no tiene presupuestado es que, por supuesto, Celestina tornará esas palabras en su beneficio. Utilizando a Areúsa como simple medio de intercambio, Celestina le dice indirectamente a Pármeno: "Y assí mismo que, pues que esto por mi intercessión se haze, que él me promete de aquí en adelante ser muy amigo de Sempronio y venir en todo lo que quisiere contra su amo en un negocio que traemos entre manos. "Es verdad, Pármeno? ¿Prométeslo assí como digo?» A lo que Pármeno responde: «Sí prometo, sin dubda.» Sin tener plena conciencia de lo que acaba de ocurrir, Pármeno consigue a Areúsa aunque entregándose a Celestina, tal como queda patente en el aparte de la alcahueta: «iHa, don ruyn! ¡Palabra te tengo! ¡A buen tiempo te así!» (VII, 3, 393).

Si el tema de la amistad entre Sempronio y Pármeno, y la alianza de estos con la alcahueta está resuelto, si no desde el Acto I, al menos desde el VII, me parece que los lamentos de traición que acometen al joven al despertar al día siguiente con Areúsa son un absurdo: « $\bigcirc$ traydor de mí! $¡$ En qué gran falta he cáydo con mi amo!» (vII, 1, 399). ¿Por qué razón tendría Pármeno que recriminarse una traición en contra de su amo tan avanzada la obra, si desde un principio está resuelto a ir en su contra?

Snow interpreta estas palabras de Pármeno desde la idea de que el personaje, en tanto individuo perverso que buscará medrar a toda costa, desea fingir fidelidad al amo para no perder su imagen. ${ }^{25}$ Algo de razón puede tener, sin embargo pienso que esta traición tiene que ver también con que Pármeno acaba de realizar un acto absolutamente réprobo, puesto que va contra la organización social, sus ideales de virtud y su pretendida libertad. Teniendo una relación con Calisto de amo y siervo, basada en la promesa de mercedes, vemos que Pármeno acaba de adquirir otro contrato de iguales características con Celestina. Considerando el modo en cómo Pármeno considera el ideal de relación entre amo y siervo - la fidelidad que es la mayor cadena que el amor del servidor al servicio del señor prende- este se ve atado a la fidelidad de un nuevo amo con cuyos ideales concuerda aún menos, y finalmente se ve en la obligación de pretender una amistad por interés con Sempronio. Empeñando su palabra de amistad, Pármeno no sólo ha traicionado a Calisto, sino también a sí mismo.

Volviendo, entonces, a la premisa de Maravall de que las relaciones de subordinación son engendradoras de vida social, es necesario considerar entonces que el orden del mundo que se presenta en La Celestina no puede ser comprendido únicamente en un esquema vertical de doble determinación, sino que requiere la consideración de las diferencias entre el mundo detentado por Calisto y los suyos, el mundo propuesto por las actividades 
de Celestina y, la condición indefinida de Pármeno; su aparición como individuo que desea fijarse en un orden tradicional inexistente y que, precisamente por esos deseos y la inexistencia de una realidad acorde, queda instalado entre ambos modelos viciados en búsqueda de medrar.

Para Pármeno la posibilidad de surgir en la sociedad y lograr identificarse con sus ideales de virtud es una tarea imposible, en la medida en que tal identificación supone la aceptación de una sociedad regida por intereses personales absolutamente egoístas: en un principio Celestina le presenta su negocio como parte de una empresa en la que las ganancias se repartirán igualitariamente, sin embargo, desde el momento en que obtiene a Areúsa y Celestina sella su trato no con un contrato sino con una promesa, es que Pármeno se da cuenta de que la sujeción con Celestina es la misma que con Calisto. Bajo esos criterios y ante la imposibilidad de medrar, se compone como un radical libre que transita de un lado a otro buscando satisfacer sus necesidades contingentes, despreciando cualquier afiliación productiva.

No diré que el final de Pármeno es completamente digno de imitación, pero tampoco me parece que sea suficiente para que lo tildemos de perverso o maligno de buenas a primeras. Quizás el drama que vive el joven sirviente haya que entenderlo en el cruce sin solución fácil entre dos ideas de amistad, junto a las respectivas jerarquías sociales y posibilidades de libertad que estas conllevan. ${ }^{26}$ Ya mencioné que para el pensamiento político de fines de la Edad Media la amistad constituía un problema central, ya que mediante ella se establecía el lazo social que conjuntaba tanto la persecución individual de la felicidad como la de la comunidad. Ahora bien, el problema surge en el momento de pensar qué es aquello que define aquella felicidad buscada y cómo es posible conseguirla: Calisto parece verla sólo en su deleite con Melibea y, por lo tanto, la utilización de Celestina no puede ser sino beneficiosa; Celestina, en concordancia, parece concebirla principalmente en el provecho que le otorga tal deleite.

26.- Para un análisis de la idea de Libertad en La Celestina en términos materialistas, véase Jesús G. Maestro, «Idea de Libertad en La Celestina desde el materialismo filosófico como teoría de la literatura», Celestinesca, 32 (2008), pp. 191-207. En este artículo se describen las formas que toma la idea de libertad en las acciones y relaciones de los distintos personajes de la obra dentro del marco específico que proyecta la sociedad de la época. Respecto de Pármeno, Maestro comprende su desenlace a partir de la renuncia que hace el personaje de su libertad para ayudar a Calisto y su sometimiento a una teleología ajena, en la que participa como consecuencia y no artífice. Ante el comportamiento de su amo y la seducción de Celestina, Pármeno termina por rechazar la razón, porque en el mundo que le toca vivir no sirve. Según él, en consecuencia, Pármeno actuará conforme a este postulado, pero sin iniciativa propia, siguiendo los dictados ajenos. Mi interpretación, como se aprecia a lo largo del artículo, está de acuerdo con el primer presupuesto de Maestro, en la renuncia a una forma de libertad sustentada en la fidelidad al amo, pero no en la renuncia a la búsqueda de la felicidad. El problema es que una vez asumida otra forma de sumisión análoga a la que tenía con Calisto, Pármeno se da cuenta de la inutilidad de sus esfuerzos. Su reacción, por lo tanto, devendrá en un accionar de carácter «nihilista» o «pesimista». 
Pármeno, por el contrario, parece verla sólo en la abnegación que viene junto a la "pobreza alegre» y al desinterés, puesto que ambos parecen ser procedimientos juiciosos y racionales ante la vida.

Jean-Baptiste Crespeau explica en su artículo sobre el concepto filosó co de felicidad en La Celestina que en el concierto de las disputas filosó co-teológicas de la época, este concepto se ve afectado directamente por la división que existe entre filosofía (ciencia) y teología, entre razón y fe. De tal forma, "la felicidad en sí corresponde primeramente a la beatitud ultraterrenal, o sea la contemplación de Dios, que sólo se puede alcanzar después de la muerte y el juicio final —esta es la vertiente teológica-. Sin embargo, se puede hablar todavía de felicidad desde una perspectiva filosófica y más precisamente política y ética, esto es, de una felicidad mundana, siempre que no interfiera con la beatitud teológica» ${ }^{27}$

A partir de esta división se desprende una concepción del mundo terrenal que no deja de ser conflictiva y "pesimista». Siguiendo el desarrollo filosófic del concepto de felicidad, desde Aristóteles hasta Boecio, queda en claro que la felicidad es el bien supremo, el fin del hombre. Entendiendo que lo que diferencia a los hombres de los animales es su razón, o su alma, se entiende que la felicidad concierne a estas entidades. El problema es que al ser un bien perfecto, vinculado desde la vertiente teológica a la verdad y a Dios, su presencia en el mundo terrenal, caracterizado por una inestabilidad fundamental, se vuelve difícilmente posible. Quizás perceptible a través de la contemplación de la naturaleza y el cosmos a través de un ejercicio racional, pero sobre todo basado en la fe. En contraposición, durante la época se consolida además una tercera dimensión del concepto y que se menciona generalmente para ser desechada; a saber, la dimensión mundana, vulgar, más propensa al anhelo de los placeres inmediatos. ${ }^{28}$

Ante esta división en la idea de felicidad - que Crespeau ve funcionando claramente en La Celestina a través de un análisis de las voces «bienaventuranza», "felicidad», "buena andanza», en contraposición a "deleite», "provecho" y "gozo", entre otras-y la manera cómo Pármeno persiste en buscarla en la abnegación y la "pobreza alegre», podríamos decir que éste personaje sigue a Séneca al pie de la letra y por lo mismo fracasa. Fothergill-Payne indica que para Séneca el hombre sabio es libre y no obedece a nadie salvo a su razón, la que se desprende de la naturaleza. El hombre sabio aprende a ser feliz contemplando el orden natural y conformándose con él. Desgraciadamente la razón de Pármeno se desprende de un mundo en el que los amos y el orden social son ilusoriamente perfectos y armoniosos. No hay una contemplación real de la experiencia, sino que sus juicios se derivan de un mundo ideal que es inexistente. En

27.- Jean-Baptiste Crespeau, «El concepto filosófico de felicidad en La Celestina», Celestinesca, 32 (2008), pp. 114.

28.- Ibidem, p. 114-15 
consecuencia, no logra ser juicioso ante las circunstancias que lo envuelven. En otras palabras, podría decirse que Pármeno encarna el drama de una filosofía derivada de Parménides, en la que las cosas que son, son, y las que no, no, envuelta en un mundo pensado por Heráclito.

En este sentido, quiero concluir señalando que, a mi entender, no hay nada naturalmente perverso en el mundo de La Celestina, salvo la utilización irracional y aplicación interesada de las sentencias morales repartidas en manuales y enseñanzas superficiales. Considerando las alusiones al mundo jurídico y filosófico y la crisis de las relaciones sociales en las que se desenvuelven los personajes, me parece ver que, si es que hay un fin didáctico o moralizante en La Celestina, éste es provocar la capacidad de juicio a partir de los conflictos representados, considerar los elementos a partir de la razón y el criterio que ésta debe conllevar, y no dejarse convencer por una serie de tópicos comunes sostenidos más por ignorancia e interés.$^{29}$ Los contrastes que se dan entre Pármeno y Areúsa podrían ser fiel testigo de esto.

29.- Propuesta que, me parece, cobra sentido claro al ser vista dentro de las «contiendas intelectuales» de la época, dentro de las que se sitúa La Celestina. Sobre todo, tal como lo explica José Luis Canet, a partir de las discusiones en contra de la Lógica y sus usos dialécticos y silogísticos. Véase, José Luis Canet, «La Celestina en la 'contienda' intelectual y universitaria de principios del s. XVI», Celestinesca, 32 (2008), pp. 85-107. 


\section{Obras Citadas}

Asenjo GonzÁlez, María, "La historia y la sociedad urbana en la lectura de La Celestina», Celestinesca, 32 (2008), pp. 13-35.

Ayerbe-Chaux, Reinaldo, "La triple tentación de Melibea», Celestinesca, 2.2 (1978), pp. 3-12.

Barón Palma, Emilio, «Pármeno: La liberación del ser auténtico, el antihéroe», Cuadernos Hispanoamericanos, 317 (1976), pp. 383-400.

CANET, José Luis, "La Celestina en la 'contienda' inteletcual y universitaria de principios del s. XVI», Celestinesca, 32 (2008), pp. 85-107.

Crespeau, Jean-Baptiste, «El concepto filosófic de felicidad en La Celestina», Celestinesca, 32 (2008), pp. 109-29.

Deyermond, Alan, "Divisiones socio-económicas, nexos sexuales: La sociedad de La Celestina», Celestinesca, 8.2 (1984), pp. 3-10.

-, "Hilado-Cordón-Cadena: Symbolic Equivalence in La Celestina», Celestinesca, 1.1 (1977), pp. 6-12.

Fothergill-Payne, Louise, Seneca and Celestina, Cambridge, Cambridge UP, 1988.

GaYLORD, Mary Malcolm, "Fair of the World, Fair of the Word: The Commerce of Language in La Celestina», Revista de Estudios Hipánicos, 25.1 (1991), pp. 1-27.

GiL-Oslé, Juan P, «La Amistad, el remedio de la Fortuna en La Celestina», Celestinesca, 29 (2005), pp. 171-95.

Heusch, Carlos, "Las desviaciones de Pármeno o la caída de un ángel», Celestinesca, 26 (2000), pp.29-44.

Heyking, John von, "The Luminous Path of Friendship: Augustine's Account of Friendship and Political Order», en Friendship \& Politics: Essays in Political Thought, ed. John von Heyking and Richard Avramenko, Notre Dame, U of Notre Dame P., 2008, pp. 115-38.

Kempshall, M. S., The Common good in Late Medieval Political Thought, Oxford, Oxford UP, 2000.

LaCARRA, María Eugenia, "La parodia de la ficción sentimental en La Celestina», Celestinesca, 13.1 (1989), pp. 11-30.

Maestro, Jesús G., «Idea de Libertad en La Celestina desde el materialismo filosófic como teoría de la literatura», Celestinesca, 32 (2008), pp. 191-207.

Maravall, José Antonio, El mundo social de La Celestina [1964], 3ª ed. Madrid, Editorial Gredos, 1986.

NirenberG, David, "Mass Convertion and Genealogical Mentalities: Jews and Christians in Fiftienth-Century Spain,» Past and Present, 174 (2002), pp. 3-41.

Rojas, Fernando de, La Celestina: Comedia o Tragicomedia de Calisto y Melibea, ed. Peter E. Russell, $3^{a}$ ed. Madrid, Clásicos Castalia, 2001. 
Schaefer, David Lewis (ed.), Freedom over Servitude: Montaigne, La Boétie, and On voluntary servitude, Westport, Greenwood Press, 1998.

SeVERIN, Dorothy Sherman, "La parodia del amor cortés en La Celestina», Edad de Oro, 3 (1984), pp. 275-279.

Snow, Joseph T., "¿¿Con qué pagaré esto?': The Life and Death of Pármeno", en The Age of the Catholic monarchs, 1474-1516: Literary Studies in Memory of Keith Whinnom, ed. Alan Deyermond and Ian Macpherson, Liverpool, Liverpool UP, 1989, pp. 185-92.

-, "Celestina's Claudina", en Hispanic Studies in Honor of Alan D. Deyermond: A North American Tribute, ed. John S. Miletich, Madison, The Hispanic Society of Medieval Studies, 1986, pp. 257-77.

Tozer, Amanda J. A., "La identidad masculina en Celestina: la emasculación de Pármeno", Celestinesca, 27 (2003), pp. 149-46.

Treusdell, William D., "Pármeno's Triple Temptation: Celestina, Act I», Hispania, 58.2 (1975), pp. 267-76.

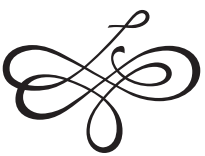




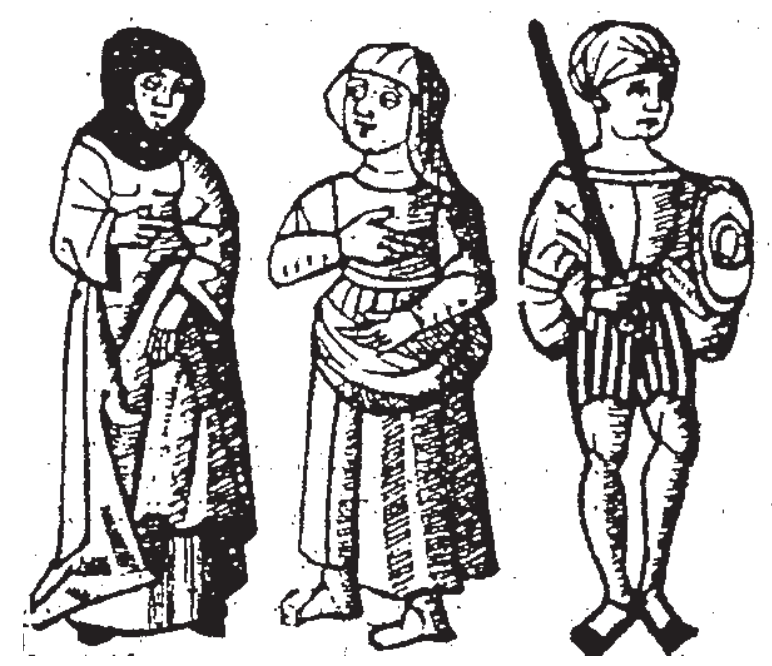




\section{Bernaschina Schürmann, Vicente, "Las políticas de la amistad en La Celestina: el caso de Pármeno", Celestinesca, 34 (2010), pp.}

$9-28$.

\section{RESUMEN}

Mediante el estudio del caso de Pármeno, el presente artículo observa la centralidad que tiene el tema de la amistad en La Celestina en cuanto medio y fin para romper y generar relaciones sociales de subordinación. Analizando las ideas sobre la amistad de este personaje que se desprenden principalmente de sus debates con Celestina - pero también en contraste con los perosnajes de Calisto, Sempronio y Areúsa- este artículo establece cómo la amistad dentro de La Celestina se tematiza en cuanto institución ético-política en disputa y de cuya dilucidación racional y juiciosa depende el orden y el destino de la sociedad.

Palabras Clave: Celestina, Pármeno, amistad, ética, política.

\section{ABSTRACT}

Through the study of Pármeno's case, this article observes the centrality the topic of friendship has in La Celestina, considered as means and ends to dislocate and to generate social relationships of subordination. Analyzing the ideas on friendship of this character, which stem mainly from his debates with Celestina -but also in contrast with other characters as Calisto, Sempronio, and Areúsa- this article establishes how friendship in La Celestina is thematized as an ethic-political institution in dispute from whose rational and sensible elucidation depends the order and destiny of society.

KEY WORDS: Celestina, Pármeno, friendship, ethics, politics. 